УДК 791.236.045:502.3/.7](045)

ORCID ID: https://orcid.org/0000-0002-17-07-16-52

Мусієнко Оксана Станіславівна,

член-кореспондент Національної академії мистецтв України, заслужений діяч мистецтв України, кандидат мистецтвознавства, професор, професор кафедри кінознавства.

Київський національний університет театру, кіно і телебачення імені І.К. Карпенка-Карого, Київ

Oksana Moussienko,
Corresponding member of the Ukraine Honored figure of arts of Ukraine, Candidate in Study of art,

Professor, Professor of cinematology Departament. Kyiv National I.K. Karpenko-Karyi Theatre, Cinema and Television University, Kyiv

\title{
СИМВОЛІКА СТИХІЙ ЯК СМИСЛОУТВОРЮЮЧИЙ ФАКТОР У КІНЕМАТОГРАФІ
}

Анотація. Метою статті є дослідження впливів символіки природних стихій на образну систему аудіовізуальних мистецтв, кінематографа зокрема. Авторка аналізує фільми, де ці впливи проявилися найбільш виразно, а саме твори О. Довженка, Ж. Віго, Ф. Фелліні, А. Тарковського, Ю. Іллєнка.

Ключові слова: символ, архетип, міфологема, поетика, стихія.

Постановка проблеми та актуальність дослідження. Система символів охоплює майже всі сфери людської діяльності, корінням своїм сягаючи у глибини віків. Сутність символа неможливо визначити однозначно. Так, це знак, але він має в собі безкінечний ряд значень, його зміст не зводиться до обмеженого тлумачення, несучи в собі глибоко приховані смисли. Пізнання їх сутності, їх осягнення і передбачає активну діяльність мислячого суб'єкта.

Метою даної статті є аналіз системи смислів, зокрема символів стихій у мистецтві і кіномистецтві зокрема, їх місце у поглибленні змісту екранних образів, набуттю ними багатобарвності і неочікуваних трактувань.

Аналіз сучасних досліджень і публікацій. Теоретичне узагальнення цієї проблематики надали такі знанні мислителі, як Е. Кассірер, П. Флоренський, К.-Г. Юнг, Г. Башляр, Ж. Дельоз. Їхні праці становлять наукове підгрунтя дослідження.

Філософ Ернст Кассірер трактував людину як «тварину символічну», максимально розширюючи поняття символічних форм, відносячи до них мову, релігію, мистецтво і науку. Вчений вважав, що саме через символічну діяльність людина може пізнати світ у всій його повноті і гармонізувати хаос, в який вона занурена. Символічні форми забезпечують контакти, єднання людей.

Православний мислитель Павло Флоренський вважав символіку мовою всіх народів. Отже, символ постає як ідеальне відображення явищ і процесів, як знак або образ, відіграючи особливу роль у сфері гуманітарного знання. Тісно взаємодіють і взаємовпливають символічні системи в міфології, релігії, мистецтві. Особливе місце в них посідає символіка природних стихій.

Наукова новизна дослідження полягає саме у в аналізі у цьому аспекті творів знаних кіномитців: О. Довженка, Ж. Віго, Ф. Фелліні, А. Тарковського, а також наших сучасників, зокрема, Ю. Іллєнка і В. Васяновича. Використані аналітичний

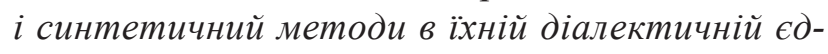
ності, а також компаративістський підхід, що дає можливість простежити спільність і розбіжність використання символіки стихій кіномитцями різних стилів і напрямів.

$$
* * *
$$

Ще в античності в центрі уваги людини перебували чотири основні стихії: вогонь, вода, повітря і земля, власне ті, з яких і творився космос. 
Сюди ж часто долучали похідні від них, такі як метал, ефір, камінь.

Основні стихії мали в собі амбівалентні значення. Так, вогонь міг бути символом перемоги життя і світла над мороком і темрявою, нести в собі функцію очищення від гріхів і скверни. Та разом 3 тим тут була наявна і небезпечний руйнівний бік цієї стихії, що виступав як небезпека тотального знищення, поглинання всього живого пекельним полум'ям. Міфологічна свідомість пов' язувала вогонь 3 чоловічим началом, 3 агресивною сексуальністю.

Натомість вода у міфологічних уявленнях вважалась втіленням жіночності, могла бути символом чистоти, правдивості, чесності. Але, як і у тлумаченні стихії вогню, вода сприймалась і як символ очищення, так і дещо загрозливе і небезпечне. У темних вирах ховалися сили, що несли в собі руйнацію і смерть. Жорстокі повені поглинали людей і творіння їх рук. Згадаймо лише біблійний переказ про великий потоп, що має свої інваріанти у різних релігіях і міфологіях світу. Як і стихія вогню, символіка води має в собі подвійні смисли, виступаючи і життєдайною, і смертельно небезпечною.

Так само у міфології трактувалась і одна 3 «невловимих» невидимих стихій - повітря. Люди відчувають його рух - вітер, він може бути ніжним і ласкавим, але, перетворившись на бурю, ураган, також несе руйнацію і смерть. Рух вітру символізує свободу і незалежність людського духу. Згадаймо лише біблійний вислів - вітер, тобто дух, віє, де хоче.

I, нарешті, земля, стихія, що уособлювала стабільність, плодючість, спокій. Як і стихія вогню, води, повітря, земля у прадавні часи ставала об'єктом обожнювання, релігійного поклоніння. Як і вода, вона найчастіше ототожнювалась 3 жіночим, саме материнським началом, зі зрілою жінкою, в той же час, як вода, символізувала юність і цноту.

Найтіснішим чином земля пов'язувалась із магією, насамперед із землеробськими обрядами. Провести першу борозну в полі було священною місією царя-жерця. Земля сприймалась як рідний дім людини, куди вона неодмінно поверталася наприкінці своєї життєвої подорожі. Археологи знаходять численні поховання прадавніх людей, де покійника клали в позі ембріона, що символізувало повернення в материнське лоно.

Природно, що міфологічне мислення, людські фантазії населяли сфери стихій нереальними, дивовижними створіннями, що живлять уяву митців.
У античні часи стародавній грек бачив у морських хвилях прекрасних нереїд, чув їх мелодійний спів. У гірських струмках плескалися наяди, а у вітах дерев ховалися їх німфи - дріади.

Об'єднуючи античні уявлення з міфологією європейських народів, середньовічні алхіміки, зокрема знаний лікар і філософ Парацельс, вирізняли відповідно до стихій чотири групи елементалів, тобто духів, пов'язаних із силами природи. Вони поєднують у собі як безтілесність, так і матеріальне начало. Такі субстанції, що населяють стихії світового простору, можуть набувати певних конкретних форм. Духи вогню уявляються прудкими, гнучкими золотими ящірками - саламандрами, які спокійно можуть перебувати в самому вирі полум'я і ніщо не зашкодить їм.

Ундіни, духи води, у слов'янській міфології ототожнювались із русалками, мавками. Вони уявлялися прекрасними юними дівчатами, які зненацька виринали з озер та річок, причаровуючи рибалок своїми співами і заманюючи їх у глибини вод. Саме ці образи знайшли широке втілення в мистецьких творах, особливо в епоху романтизму. Тут і поезія - «Лореляй» Г. Гайне, драматургія - «Потонулий дзвін» Г. Гауптмана, слід згадати і безсмертну феєрію Лесі Українки «Лісова пісня». Власне, у творі української поетеси ми зустрінемося майже з усіма поетичними втіленнями стихій - $\mathrm{i}$ русалкою, і 3 духом вогню Перелесником, і $з$ персоніфікацією нестримної сили води - «Той, що греблі рве».

Сильфи і сильфіди, за віруваннями середньовічних європейців, були духами повітря. Інколи їх ототожнювали з феями та ельфами. I знов-таки мистецтво черпало своє натхнення в образах цих легких, прозорих світлих створінь. Згадаймо, саме дух повітря Арієль служив мудрому чарівникові Просперо у філософській п’єсі-казці «Буря» В. Шекспіра.

Земля у системі символів постає як початок і кінець усього живого. Вона і добра мати, що нагодує своїх дітей багатим врожаєм, і останній прихисток, де кожна людина завершить свій шлях. У міфологіях світу Земля пов'язується 3 хтонічними образами потойбічних сил, які несуть у собі загрозу людині. Середньовічні легенди населяють таємничі підземні печери створіннями-гномами, які вільно рухаються крізь земну твердь, добуваючи дорогоцінні метали і каміння, що несуть людям як багатство, так і ворожнечу та розбрат. Варто згадати лише знаний давньогерманський епос «Пісня про Нібелунгів».

Із землею пов'язані стародавні вірування і обряди, що мали як еротичний характер, так 
і виливались у жорстокі офірування, коли поля кропилися кров'ю жертв. Своєрідним інваріантом образу землі можуть бути скелі й гори, які грізно здіймаються над земною твердю. Міфологема гори теж є однією з найпоширеніших у різних народів. Гора часто трактується як своєрідне поєднання землі з небесними сферами, як шлях до обійстя богів.

Втім, не лише історичне минуле дає можливість осмислити символіку природних стихій, які визначають саму сферу існування людства, і виявити їх впливи на творчі процеси, на світосприйняття митця, його відчуття світу і місце людини у ньому. Цей мистецький аспект розглядали і аналізували філософи різних напрямків і уподобань, такі як Карл-Густав Юнг, Гастон Башляр, Жиль Дельоз. Саме в їх працях бачимо оригінальний, своєрідний підхід до проблеми впливу символіки природних стихій на характер творчості у найрізноманітніших галузях мистецтва.

Безперечно, однією з найцікавіших є позиція Башляра, де автор пов'язує з певною природною стихією саму творчість того чи іншого митця. Це знайшло відображення у знаній пенталогії французького філософа, що складається з книг «Психологія вогню», «Вода і мрії», «Повітря і сновидіння» і двотомника - «Земля і мрії волі», «Земля і мрії про спокій». На думку філософа, творча уява має «знайти свою матерію, щоб яка-небудь з матеріальних стихій віддала йому притаманну їй субстанцію, притаманні їй закони, характерну для неї поетику» (Башляр, 1998, с. 19).

Так, Башляр виділяє Т. А. Гофмана як митця вогню, Е.А. По як такого, що за типом своєї уяви належав до митців стихії води, Ф. Ніцше він вважав поетом польоту, відриву від землі, танка в повітрі. Серед тих, хто пов'язаний за своєю уявою зі стихією землі, названо Ж.-К. Гюйсманса і Г. Мелвілла. Поетами землі Башляр вважав також А. Блока, С. Ссеніна.

Стихії, за Башляром, що з давніх-давен допомагали філософам представити всю велич світобудови, $є$ також і першоначалами художньої творчості. I хоч вплив їх на уяву може здатися досить дотичним і метафоричним, вони є основою цілісності мистецького творіння, допомагають не лише розуміти художній образ, а і переживати його. Людина, на думку Башляра, це не лише мисляча тварина, а й така, що здатна марити.

Певним чином наслідує Башляра інший французький філософ, Жиль Дельоз, автор фундаментального дослідження «Кіно», вводячи для тлумачення кінообразів поняття стихій, точніше їх якостей, а саме твердого, рідини і газоподібного. 3 ними він пов'язує ступінь «перцептивної свободи» митця. Перехід від твердого до рідини і далі до газоподібного характеризує пластичність і гнучкість сприйняття руху.

Природно, що філософа найбільше привертає стихія води, бо французькі кіномитці від імпресіонізму до «поетичного реалізму» були буквально закохані у водну стихію. За Дельозом любов до води притаманна всій французькій школі, що «знаходить вияв у показі то ріки та іiі течії, то каналу $з$ його шлюзами і вітрильниками, то моря, його межі із суходолом, порту, маяка як світлового фону» (Дельоз, 2004, с. 132).

Дельоз дає відповідь, чому саме стихія води відповідає всім вимогам французької школи, її естетично абстрактному, документальносоціальному і оповідно-драматичному критерію. «У першу чергу тому, що вода являє собою основне середовище, із якого можна видобути рух рухомого предмета або рухомість самого руху: звідси оптична і звукова важливість води у дослідженні ритму» (Дельоз, 2003, с. 132). Рухома стихія води перетворюється на екрані у «конкретне середовище мешкання конкретного людського типу, певної людської раси, представники якої живуть зовсім не так, як мешканці суходолу, інакше сприймають події, інакше відчувають» (Дельоз, 2004, c. 132).

Серед митців, які створювали драматичну напругу і поетичну тональність на протиставленні «перцепції, переживання і дії мешканців суходолу з одного боку, і дії людей води - з іншого боку» (Дельоз, 2004, с. 133), філософ називає Ж. Ренуара 3 його захопленням течією водної стихії, Л’Ерб’ $€$, який задумував у «Бурхливому потоці» воду зробити головною героїнею фільму, Ж. Епштейна, що протиставив земну твердь плинності неба і води, Ж. Гремійона, який простежував драматичні стосунки Людини і Стихії в своїх фільмах. І все ж, на думку Дельоза, «найвища точка подібної опозиції досягається в “Аталанті” Віго» (Дельоз, 2004, с. 139).

Дослідник звертає увагу на різний характер руху на землі і на воді, їх «різну “грацію”: рух по суходолу пов' язаний з постійним порушенням рівноваги $<\ldots>$ а ось акватичний рух збігається з переміщенням центру тяжіння» (Дельоз, 2004, с. 133). Пейзаж у «Прекрасній Нівернезці» Ж. Епштейна - спокійна поверхня ріки, в дзеркалі якої відображаються зарослі деревами і чагарником береги. Легкі, прозорі хмаринки неначе акомпанують почуттям закоханих, що здається розлиті у всій природі. 
Стихія води стає і смислоутворюючим, і емоційним фактором надзвичайної сили. Чи не тому «Аталанту» охоче цитували режисери майбутніх поколінь. Фінал «Аталанти», де закохані стоять на палубі баржі, що гойдається на хвилях, надихне Л. Каракса на завершення своєї стрічки «Коханці Нового мосту» прямою цитатою з фільму Віго.

Поза сумнівами $є$ впливи аналітичної психології К.-Г.Юнга, його вчення про символ і архетип, взаємозв'язок цих понять, їх вияв у глибинній течії мистецьких процесів. Переконливим прикладом може стати творчість Федеріко Фелліні, що у своїх фільмах охоче вдавався до використання символів і міфологем. За висловами самого режисера, підхід до символу як до засобу, що сприяє виявленню невиявленого, проникненню у вічні таємниці людської душі, митець знайшов саме у Юнга.

Фелліні вважав швейцарського філософа своїм провідником у найважливішій подорожі у житті, «подорожі усередину самого себе». Як Вергілій у Дантовому пеклі, Юнг допомагав митцеві йти небезпечними стежками самопізнання, оминаючи темні прірви позасвідомого. Митцеві надзвичайно імпонувала «наукова смиренність» Юнга перед таємницями життя:

Його думки, його ідеї не претендують на те, щоб стати доктриною, їх мета - лише показати нову точку зору, інше ставлення, яке може збагатити і розвинути твою особистість, привести тебе до більш свідомої і відкритої чутливої поведінки і примирити з утаємниченим задавленим. (Фелліні, 1988 , c. 82$)$

Кіномитцеві інколи здавалось, що Юнг написав усе спеціально для нього. Особливо Фелліні вражало трактування сновидінь як архетипічних образів, що $є$ результатом колективного досвіду людства, бачення Юнгом символу як засобу висловити невисловлюване, відхилити завісу над вічними таємницями, стимулювати інтуїцію. Звичайно, твори Фелліні аж ніяк не $є$ ілюстрацією до філософських ідей автора «глибинної психології», але саме у Юнга можна знайти ключ до образної системи фільмів італійського режисера.

Природні стихії у Фелліні-це віддзеркалення певного душевного і духовного стану, свого роду система символів, що допомагає зазирнути у внутрішній світ. Як митець режисер багато в чому зберігав вірність естетиці неореалізму: вміння передати картини навколишнього світу, точне бачення деталі i, головне, щире співчуття звичайній людині у іiі життєвих поневіряннях. I разом з тим природа в його фільмах набирає символічного забарвлення. Це вже не просто пейзажі, це певні стихії, відображення яких стає ключем до мистецьких образів.

Так, жіночі образи Фелліні найтісніше пов'язані зі стихією води. Це можна простежити майже у всіх фільмах митця. На березі моря ми вперше побачимо Джельсоміну (Дж. Мазіна), перед тим як вона вирушить у свою сумну подорож із жорстоким Дзампано (Е. Квінн). У фіналі фільму «Дорога» ми знову побачимо морський простір. I хоч у кадрі й не буде маленької клоунеси, іiї незрима присутність зберігається в цьому епізоді. Саме на пустельному березі моря під холодними далекими зорями, як поранений звір, ридатиме Дзампано, усвідомивши свою безнадійну самотність після смерті тієї, яку він так підло зрадив і покинув напризволяще.

У струменях фонтану Треві побачимо ми кінозірку в «Солодкому житті», що всіх вражає своєю сяючою, переможною красою. Та ось фонтан вимкнуто, і ця жінка з мокрим волоссям, що втратило свою пишність, у безформній, облиплій сукні виглядає безпорадною і жалюгідною. Разом 3 магією води зникає велична богиня Юнона, натомість бачимо розгублену актрису, яка ще й отримує ляпаси від свого продюсера.

Юна дівчина на березі моря з'явиться перед спустошеним нічною оргією Марчелло (М. Мастроянні) у фільмі «Солодке життя». Та марно він звертатиметься до неї. Вона не почує його за шумом хвиль, ітиме все далі й далі. А море зі своїх глибин винесе огидне мертве чудовисько, що постане перед очима героя фільму як символ його безнадійного, безсенсового існування.

У картині «8 1/2» серед паноптикуму гротескних персонажів режисер Гвідо (М. Мастроянні) побачить біля цілющого джерела постать юної дівчини, яка лишиться для митця втіленням світлого ідеалу. Ось як трактував іiі сам Фелліні в одному зі своїх інтерв'ю: «Уяви собі Клаудію Кардінале, прекрасну, ще зовсім молоду, але духовно зрілу дівчину, дар самобутності якої наш герой вже не здатний прийняти» (Фелліні, 1984, с. 83). Гвідо вже не допоможе цілюща вода, яку йому запропонує дівчина біля джерела, так само, як він не зможе пояснити юній актрисі (ії знов-таки грає Клаудія Кардінале) ні сутності їі ролі, ні задум самого фільму.

Пов'язуючи чисту і світлу постать із життєдайним джерелом, Фелліні разом з тим виявляє двоїстість як водної стихії, так і жіночої натури. На морському березі з'являється таємнича, страшна і разом з тим гіпнотично приваблива Сарагіна. Цей образ жінки, наділеної якоюсь незбагненною тваринною грацією, був принципово важливим для 
автора. Режисер довго шукав виконавицю, серед «фантастичних і спокусливих чудовиськ, неосяжні тіла, розпатлані гриви, погляди косі, підозрілі та разом 3 тим - материнські» (Фелліні, 1984, с. 90) Фелліні знайшов те, що шукав:

Сарагіна - це саме моє дитяче уявлення про жінку, одне з багатьох тисяч найрізноманітніших проявів, на яке тільки здатна жінка. Сарагіна, щедро наділена якоюсь тваринною жіночністю, велетенська, неосяжна і водночас привабливоапетитна. (Фелліні, 1984, с. 90)

Для переляканого хлопчика, що спостерігає iii танець на березі моря, ця жінка сприймається як утілення привабливого гріха і разом 3 тим як загадковий і грізний образ матері. Як зауважував сам Фелліні, «повія - це свого роду контрапункт, головна супутниця матері по-італійськи» (Фелліні, 1984, с. 91). Так з глибин позасвідомого з'являється образ хтонічного божества, що його втілює повія Сарагіна.

Тут знову згадаємо К.-Г.Юнга, чиї погляди так багато важили для Фелліні. Для швейцарського філософа саме водна стихія найчастіше стає символом позасвідомого, «означає дух, що стає позасвідомим». Саме $з$ водою Юнг пов'язує амбівалентність жіночого начала. Душа жінки нагадує таємні водяні глибини.

Той, хто дивиться у воду, бачить, звичайно, своє обличчя, та скоро на поверхню починають виходити живі створіння, ними можуть бути і риби, нешкідливі мешканці глибин. Але озеро кишить привидами, водяними створіннями особливого роду. Часто в сіті рибалок потрапляють русалки напівриби, напівжінки. Русалки зачаровують... Русалки являють собою перший ступінь цього чаклунського жіночого створіння, що його ми називаємо Анімою. (Юнг, 1991, с. 114)

Своєрідним свідченням захоплення Фелліні поглядами Юнга стає таємниче слово, що його пригадує Гвідо під час сеансу читання думок. Медіум пише на дошці незрозуміле присутнім слово «Азанізімаза». I лише втаємниченим відомо, що тут зашифроване таке важливе в аналітичній психології слово «Аніма».

Роздумам над архетипом Аніми, його тлумаченню та інтерпретації відведено чимало сторінок у працях Юнга. Як і сама стихія води, архетип Аніми - амбівалентний, двоїстий. Як і сама природа, він перебуває по той бік добра і зла. Аніма може ототожнюватись із материнським началом, i3 всесильною матір'ю, яка впродовж усього життя впливає на долю людини. Віддалення від материнської опіки, перші кроки в доросле життя - процес складний і болісний. Чи не тому, як зауважує Юнг, 3 прадавніх часів існує цілий ряд церемоній і обрядів, що супроводжують і організують цю «сепарацію».

Власне кажучи, відділення від матері й визначалося як перехід у нову якість, як «ініціація». Якщо батько мав захищати сина від зовнішньої небезпеки, то «матір для нього - захист від небезпеки, що загрожує його душі з мороку» (Юнг, 2001, с. 198).

Сучасна людина, позбавлена ритуалів і обрядів ініціації, дуже часто опиняється в надзвичайно складний і кризовий для себе період дорослішання сам на сам із собою, зі своїм позасвідомим. Чи не звідти коріння всіх тих трагічних історій юнацької закоханості від «Страждань молодого Вертера» Й. В. Гете до «Митіного кохання» І. Буніна. За Юнгом, у сучасної людини «аніма у формі материнського imago переноситься на жінку, яка збуджує його почуття < ..> адже жінкам часто бувають зрозумілі речі, до яких чоловікам ще довго брести у темряві (Юнг, 2001, с. 207).

Звідки ж така сила Аніми? Юнг трактує іiі як персоніфікацію жіночої природи в чоловічому позасвідомому, позасвідомий жіночий бік психіки чоловіка. За Юнгом процеси, що протікають у внутрішньому світі людини, тим сильніше впливають на їі долю, чим більше вони мають характер позасвідомого. Філософ порівнює катастрофи глобальні і соціальні, й природні, і техногенні, ті, що відбуваються у зовнішньому світі, «де у будьякий момент може затонути континент, зміститися полюс, спалахнути нова епідемія, так і в нашому внутрішньому світі може відбутися щось подібне, тільки зазвичай у формі ідеї з не менш небезпечними і непередбачуваними наслідками” (Юнг, 2001, c. 207).

Повертаючись до творів Фелліні, ще раз переконуємось, наскільки важливими для митця у відтворенні як людських особистостей, так і простору, космосу його фільмів були символи стихій. Можна сказати, перефразуючи Башляра, що стихії справді були першоджерелами творчості італійського режисера.

Так, щоб наголосити, акцентувати брутальну мужність, навіть звіроподібність Дзампано у «Дорозі», Фелліні вводить стихії вогню і заліза. Під час циркового номера атлет має розірвати, напружуючи м'язи, залізний ланцюг - на килимі навіть вдень чадно горить каганець. Його вогник такий самий символ Дзампано, як і Саламандра, дух вогню, що витатуюваний на його руці. Найбільшу лють цього похмурого велетня викликають навіть не жарти 
і глузування акробата Матто, а те, коли той виплескує на нього відро холодної води. На екрані неначе матеріалізується вибухова реакція, коли у непримиренному двобії зіткнулись ворожі стихії.

Постать Матто теж позначена приналежністю до певної стихії - повітря. Він - акробат і свої ризиковані трюки виконує просто неба на канаті, натягнутому у височині. Амбівалентність постаті Матто артикулюється і його цирковим костюмом, що поєднує в собі риси янгола і пекельного духа. Легкий і швидкий, як повітря, Матто наділений гострим, спостережливим розумом. Він може все пізнати і оцінити, але не здатний на глибокі почуття. Тому Джельсоміна і залишиться 3 жорстоким Дзампано, бо інстинктивно відчує байдужість і холодність Матто.

Чи не тому Фелліні пов'язує своїх героївінтелектуалів зі стихією повітря. І разом акцентує їх нездатність вільно злетіти. У «Солодкому житті» глядач уперше побачить Марчелло у кабіні гелікоптера, що летить над дахами і терасами вічного міста. Журналіст насолоджується сонячним днем, ширянням у потоках повітря, заграє 3 дівчатами, що засмагають на терасах.

До корпусу гелікоптера прив'язано статую Спасителя, який простер руки над Вічним містом. Просте логістичне дійство - перевезення скульптури повітряним шляхом - викликало і обурення, і захоплення; що це - профанація сакрального чи утвердження віри в те, що божественне начало не покинуло цей грішний і зіпсований світ?

А журналіст Марчелло пройде крізь увесь фільм, як людина, яка споглядає, спостерігає, не переймаючись пристрастями і стражданнями людей, котрі ії̈ оточують. Що ж, мабуть, у цьому він вбачає сутність своєї професії, а радше й своєї природи, невагомої, як повітря. Втім, Фелліні приведе нас до думки, що це може обернутися «нестерпною легкістю буття», і всі буремні пристрасті світу затягнуть Марчелло у свій вир.

Як споглядальна особистість сприймається і Гвідо Ансельмі, втілений знов-таки Мастроянні у стрічці «8 1/2». Ті люди, які трапляються на шляху режисера, їх долі, їх життєві колізії-лише матеріал для творчості, образи майбутнього фільму. Як і Марчелло, Гвідо з'явиться на екрані у вільному польоті. Уві сні, охоплений майже клаустрофобічним жахом, він видирається з тісняви авто, щоб злетіти над шосе, забитому автівками, туди, де вільно дихається, у безкінечний небесний простір. Та ласо, послане міцною рукою продюсера, стягне режисера із захмарних емпіреїв на грішну землю. I митцеві, «вільному сину ефіра» теж доведеться повною мірою включитися в ту земну гру, що називається життям.

Сам Фелліні значною мірою був митцем, образні системи якого визначалися символікою повітря. Ця стихія несла для його творчості надзвичайні й часто незбагненні смисли. Це виразно виявилось у його задумі фільму про Рим, місто, яке, за його словами, було недоступним, невловимим і назавжди зберегло від нього свої таємниці. Режисер мріяв створити «фільм-символ, в якому має втілитися сама сутність Рима, його квінтесенція» (Фелліні, 1988, c. 270).

Фелліні окреслює образи, на яких він прагне будувати фільм. Як і герой його «Солодкого життя», режисер знову прагне побачити фільм з небес. «Я хотів би провести зйомку з гелікоптера. Глянути згори, як утворюються хмари, зафільмувати ці величезні різнобарвні маси, котрі зливаються разом, розпадаються на друзки, переливаються одна в одну» (Фелліні, 1988, с. 270).

I далі митець ставить собі на меті здійснити майже неможливе - зафільмувати вітер, рух повітря. «Понтіно. Де зароджується цей знаменитий вітер? Звідки він береться? Мені хотілось би захопити його від самого початку, простежити його шлях на Рим, зафільмувати людей, що відчули на собі його дію: в кафе, в ліжку, на вулиці» (Фелліні, 1988, c. 270).

Та повітря сучасного міста може виявитися нещадним до артефактів минулого. Під час будівництва римського метро відкривається гігантська підземна зала, де перед враженими очевидцями постають у всій своїй красі античні фрески. Та дивовижні барви починають бліднути і зникають, як фата моргана. Повітря, що увірвалось у підземелля, нищить цю божественну красу, виступаючи тут знаряддям невмолимого, нещадного часу.

Так само, як герої Фелліні блукають у пошуках втраченого часу, у пошуках своєї «самості», подорож «всередину самого себе» здійснюють і персонажі знаного митця - Андрія Тарковського. I так само, як у Фелліні, символіка стихій у твоpax Тарковського сприяє проникненню у глибинні шари екранного образу. Слушною є думка щодо фільмів митця. «Екран віддано у владу стихіям вогню і води, землі і повітря - чотирьом елементам всесвіту, спокійним чи бурхливим, твердим чи піддатливим» (Баткін, 1991, с. 110).

Починаючи 3 «Іванового дитинства» стихія води неначе веде свою музичну тему, що звучить як контрапункт у визначальних епізодах фільму. Вода в криниці, в глибини якої вдивляється Іван (М. Бурляєв) 3 матір'ю - сприймається як єднання 
людини з небесами. Адже саме вода дає можливість побачити невидиме для інших - зірку серед ясного дня. У водних глибинах розкривається небесна височінь. Та ось поверхня ріки, яку перетинає Іван, йдучи на своє останнє партизанське завдання. Це чорні води Стіксу, ріки смерті і забуття. Вона поглине Івана, як і мільйони інших, що зникли і розчинилися у кривавих просторах війни. Пам'ять, що лишиться, то тільки фото страченого хлопця з гестапівських документів, яке знайде капітан Холін. I разом 3 тим візуальна тема води як відродження, як вічності життя виникає у фіналі, коли Іван біжить по річковій обмілині, усміхнений, щасливий, поміж яблук, що розсипані на вологому піску.

У фільмах Тарковського герої часто застигають під дощем, який несе в собі життєдайну силу, що омиває не лише їх тіло, а й душу. Такий дощ у саду біля рідного дому подарує Крісові Кельвіну (М. Бурляєв) таємничий і могутній океан Соляріс, відроджуючи його до нового життя, повернення до самого себе. Струмені води з неба, зібрані дбайливою рукою, омиють голову жінки, забираючи і тяжкі думи про втрачене кохання, і безнадію, і зневіру («Дзеркало»).

I знову вода, як стихія, що поглинає пам'ять, що залишає людину без минулого, стоятиме непорушно в чудесній кімнаті («Сталкер»). Під іiі товщею можна буде роздивитися предмети, що є неначе знаками сучасної технологічної цивілізації, та її також безжально поглине вічність, що відбивається в нерухомій, мертвій поверхні.

Так само амбівалентною з'являється у фільмах Тарковського стихія вогню. Це може бути безжальна, нестримна сила, що поглинає нові і нові жертви. Чорніють залишки спалених хат у «Івановому дитинстві», палає церковний іконостас - творіння Андрія Рубльова. Та вогонь може бути могутньою творчою силою - адже в його полум'ї виплавиться дзвін, що своїм чистим і сильним звучанням очищатиме душі людей.

Вогонь, його полум'я як очищення побачимо у «Ностальгії» і «Жертвоприношенні». Італієць Домініко, прагнучи врятувати себе і свою сім'ю, на цілих сім років усамітнюється якнайдалі від всіх пасток і спокус сучасного прагматичного світу. Та невдовзі він доходить висновку - самому врятуватися неможливо. I Домініко вибирає страшний шлях - самоспалення просто біля статуї Марка Аврелія. Цією жертвою він сподівається врятувати приречене людство від неминучої загибелі. На цю роль було запрошено Ерланда Юсефсона, який дебютував у фільмі І. Бергмана «Над нашою любов’ю йде дощ» ще у 1946 році. Далі він зіграв у таких знаних фільмах режисера, як «Лице», «Година вовка», «Сцени з подружнього життя», «Осіння соната» та інших. Цей «бергманівський» актор надзвичайно тонко, в усіх нюансах був здатен відтворити внутрішній світ європейського інтелектуала. Тому цілком природно, що Тарковський запросив актора і в свій наступний фільм «Жертвоприношення», герой якого також одержимий ідеєю врятувати світ від атомного Апокаліпсису.

I якщо Доменіко спалює своє тіло, то Олександр спалює свій дім, знищуючи ту частину свого життя, яка 3 ним пов'язана. Цим, здавалось би, абсурдним учинком герой фільму прагне довести необхідність цієї індивідуальної жертви для загального спасіння. Так людська особистість, єдина і неповторна, здатна своєю жертовністю принести очищення і порятунок людству. Лише у такому єднанні відбувається спасіння окремої душі.

У присвячених творам Тарковського текстах відзначається наповненість екранного простору чистим, прозорим світлом. Особливо це відчувається у «Жертвоприношенні», де геніальна камера «бергманівського» оператора Свена Нюквіста відкриває глядачеві неозорі простори і широкі горизонти північного неба. Сонячні промені неначе розсіюються в холодному повітрі, роблячи його «видимим», майже матеріальним.

Поривання в небо, його відчуття, безстрашне занурення у його простір притаманне всій образній системі фільмів Тарковського. Згадаймо лише вражаючий пролог до «Андрія Рубльова», коли сміливець весь у якихось неймовірних мотузках і ремінцях, що ними прив'язані до його тіла крила, робить відчайдушний крок $з$ дзвіниці, починаючи своє переможне паріння у повітряному просторі.

Цей епізод стає своєрідним камертоном до всього фільму. Такими ж сповненими краси і відваги стануть і відливання церковного дзвону, і написання Рубльовим геніальної «Трійці». Всі ці діяння прозвучать як виправдання людини, як утвердження високого ідеалу у кривавому світі насильства і ненависті.

Людина відривається від землі, ширяє у просторі не лише як матеріальне тіло. У «Дзеркалі» ми бачимо повітряні кулі, що пливуть у височині, прикрашаючи горизонт різнобарв'ям кольорів. I разом 3 тим злітає, долаючи земне тяжіння, одна з героїнь фільму, вона спокійно застигає в повітрі зі словами «ось і я злетіла». I Тарковський підводить нас до думки, що ця жінка, яка пройшла у своєму житті найтяжчі випробування і воєнними злиднями, і зрадою, і самотністю, мала в своїй душі щось, що давало їй можливість на цей злет. Заворожують 
і кадри левітації чаклунки Марії в «Жертвоприношенні», як підтвердження іiі таємної магічної сили.

$\mathrm{Ta}$, мабуть, найбільш поетичними, наповненими глибинним змістом є кадри паріння в повітрі Кріса і Харі у «Солярисі», яке інколи порівнюють 3 творінням Марка Шагала. Вони злітають, долаючи земне тяжіння, хоч це і може знайти пояснення несподіваною появою невагомості на таємничій планеті Солярис. Але їх політ - то політ їхніх душ, політ їх кохання, в якому кожен знаходить і себе, і людину, найважливішу в його житті.

Здається, можна сказати про Тарковського, як і про Фелліні, що він все життя знімав один фільм. І весь цей «метафільм» був автобіографічним, а не лише «Дзеркало», так само, як у Фелліні не лише «Амаркорд». Перефразовуючи відомого критика, можна твердити, що тут сходяться всі лейтмотиви вітру, вогню, води, надаючи образній системі цих стрічок максимальної універсальності.

Слід зазначити, символіка стихій мала вагоме значення майже на всіх етапах існування кіномистецтва. Адже дуже швидко пейзаж на екрані перестав бути лише означенням місця дії, а став набувати смислоутворюючого значення. Ще Ейзенштейн зазначав, що для створення картини природи на екрані, він використовував елементи чотирьох стихій: повітря, води, тверді й вогню.

«І здається, що фактури окремих стихій, як і самі стихії, між собою утворюють таке ж сполучення, яким є оркестр, що об'єднує в одночасності і послідовності дії-духові і струнні, дерево і мідь" (Ейзенштейн, 1964, с. 265). На думку митця, пейзаж має таку саму партитуру у фільмі, як і всі інші.

Музику пейзажу повною мірою відчував і транслював Олександр Довженко. Особливе місце в творчості митця посідала тема землі і в зображальному, і в філософському сенсі. Варто згадати, що символіка Землі з'являється у Довженка у своїй трагічній іпостасі. В «Арсеналі»-це випалена сонцем, потріскана поверхня, геть позбавлена своєї родючості. Паралельно з кадрами виснаженого грунту ми бачимо постаті змарнілих жінок, яким уже не дано нагодувати материнським молоком своїх дітей. Ми бачимо землю, понівечену окопами жорстокої війни, розриту могилу, над якою матір чекає тіло свого сина-воїна.

Та найповніше розгорнеться міфологема землі у шедеврі митця, що увійшов назавжди в число найкращих фільмів усіх часів і народів. Сюжет картини «Земля», точніше його фабула, за своїм характером - типовий відгомін часу з його пропагандистським пафосом і однозначністю. Проте погодимося 3 думкою, що «...сюжет належить своєму часу, а назавжди лишається міф про землю - молодий, пристрасний, наївний, еротичний у найширшому розумінні цього слова. Субстанція життя, продовження життя, плодючості проноситься перед зачарованим поглядом глядача». (Якимович, 1994, с. 137-141).

Образність Довженкової «Землі» сприймалась сучасниками як співзвучна вітаїзму, тобто світовідчуттю, притаманному культурі українського Відродження 1920 pp. Вітаїстські, барокові тенденції вже проявились у процесі роботи над фільмом, про що свідчить розлогий матеріал Г. Ремеза «Патос землі» у часописі «Кіно». Автор порівнює кадри натури, яку вибрав режисер 3 «циклопічними полотнами Рубенса» або «стихійними романами Золя». У статті висловлюється впевненість, що «фільм О. Довженка “Земля” буде фільмом нечуваної ще в нашій кінематографії філософської сили, сили оптимістичного матеріалістичного розуміння тих соціальних, а як тло для них - біологічних процесів, які відбуваються в нашій країні» (Ремез, 1929 , c. 6).

Як бачимо, сам матеріал фільму вже давав привід говорити про «космічну» силу узагальнення образу Землі як життєдайного начала, як початку і кінця людського існування. I Рубенс, і Золя згадуються тут не випадково. Вже у наш час фільм Довженка розглядатиметься у контексті творчості великого французького письменника, зіставлятиметься символіка роману Золя «Земля» і стрічка українського кіномитця (Оніщенко О., 2001).

На міфопоетичний характер образності фільму «Земля» Довженка, на його глибинний зв'язок 3 найпотаємнішими пластами «колективного позасвідомого» вказує дослідник творчості митця С. Тримбач (Тримбач, 2007). Довженко у створенні системи екранних символів, пов'язаних з уявленням про світ стихій, започаткував тенденцію, що знайде своє продовження в «школі поетичного кіно».

Багатство палітри митців, яких відносять до цього напряму, вражає і сьогодні. Втім, оберемо одного з них, а саме Юрія Іллєнка, який, поєднавши в собі дві кінематографічні професії-режисера i оператора, залишив неповторні взірці поетичного i філософського бачення природи. Кадри його фільмів, що сповнені всіма барвами світу, разом з тим виростають до символів, до високих узагальнень.

У режисерському дебюті Іллєнка «Криниця для спраглих» земля, як і місце буття людини, і його одвічна годувальниця постає в своїй трагічній і неочікуваній іпостасі: вона перетворюється на пустелю, їі поглинають піски. Кадри, наділені максимальною конкретикою і фотографічною до- 
стовірністю, набувають семіотичності, несуть цілу систему додаткових конотацій.

I вже на екрані не просто таке незвичне для українського ландшафту явище - наступ пісків, а трагічна символіка смерті землі як занепаду і розкладу певної системи суспільного устрою. Так символіка природи в творах митців набуває нових значень, розкриває потаємні, глибинні смисли явищ і процесів, що відбуваються у людській спільноті. Як багато значило для Іллєнка місце дії доводять свідчення самого митця.

Лише відшукавши потрібну локацію, режисер знаходив ключ до певного епізоду або і до фільму в цілому. Так, знімаючи «Вечір на Івана Купала», митець майже зайшов у глухий кут у пошуках потрібного рішення, аж поки не натрапив у лісі на глибоке провалля, що нагадувало вхід до пекла. Як уже згадувалось, своєрідним символічним «каркасом» у «Криниці для спраглих» стало українське село, що потопає у пісках, або гори, що, як стіна, закривають небо в картині «Білий птах 3 чорною ознакою». Варто згадати слова Сергія Ейзенштейна: «Пейзаж може слугувати конкретним образом втілення космічних концепцій, втіленням цілих філософських систем» (Ейзенштейн, 1964, c. 287).

Серед сучасних кіномитців, для яких пейзаж у фільмі несе не менше навантаження, ніж у класиків поетичного кіно, слід назвати Валентина Васяновича. Для автора славнозвісної «Атлантиди» локація стає не лише ключем до того чи іншого епізоду, але, можна сказати, викликає його до життя, за словами самого режисера, керує ним. Адже, на його думку, в павільйоні можна щось змінити, а натура не піддається цим корекціям. Вона така, яка вона є. Як митець, що поєднує професії режисера і оператора, в своїй творчості Васянович іде від візуального образу. Втім, якщо пригадувати шедеври поетичної школи, то найближче «екранний живопис» Васяновича стоїть до суворої графіки «Камінного хреста» Леоніда Осики.

Можна стверджувати, в «Атлантиді» візуальний стиль режисера остаточно викристалізувався. Митець бачить світ всеохопно, як безкрайній простір, де постать людини губиться в його безкінечних вимірах. Кадр має досить чітку рамку чотирикутника, де постать людини майже непомітна в безкрайніх постапокаліптичних ландшафтах.

Цікаво, що камера не шукає в кадрі людського обличчя. Крупні плани будуть рідкістю, людина вписана в «контекст» кадру. Відтак погляд зосереджений на людській пластиці. Це видно вже 3 першого епізоду, який читається символічно -
3 позасвідомого людини неможливо викорінити пам'ять війни. Два побратими, учасники бойових дій у Донбасі, розставивши мішені, вправляються у снайперській стрільбі.

У фільмі бачимо людей, геть вирваних з нормальної течії життя. Навіть побутова дрібниця викликає нестримний, шалений спалах люті. У фільмі мало інтер'єрів. Один з них - це кімната-пустка Сергія, головного героя фільму. В цьому помешканні є лише необхідні речі: ліжко, стіл, стілець: суцільне царство прямих кутів. I немає жодної дрібнички - фотографії, якоїсь листівочки, квітки, що свідчило б - тут живе людина, що якось прив'язана до цього дому.

$\mathrm{Te}$, що час помешкань теплих, обжитих, таких, що несуть відбиток особистості тих, хто жив під ïх дахом, вже незворотно минув, продемонструє інший епізод. Це буде вже в другій частині фільму, коли Сергій блукатиме напівзруйнованою будівлею і зайде до кімнати, яку давно полишив. Він побачить розбите, покалічене фортепіано, розсипані під шаром пилу і цегли книжки, красивий, але розбитий посуд, все те, що привносило в цей будинок тепло і затишок, а тепер перетворилося на прах. Через руйнування звичайних побутових речей розкривається фатальна пустка у душі людини.

Як катастрофа на рівні землетрусу подається епізод закриття виробництва. Над однорідною масою людей височить екран, з якого якийсь високоповажний менеджер говорить цим людям, що потенціал заводу вичерпано і робітникам доведеться шукати іншої долі. Щоправда, «голова, що промовляє»-оптиміст. Він вважає, що цей доленосний злам відкриє перед робітниками нові перспективи. Цікаво подано на екрані реакцію цієї маси. Мимоволі можна згадати класичні стрічки, зокрема «Метрополіс» Ф. Ланга, де колона робітників то покірно рухається назустріч своїй долі, то вдається до бунту, безсенсовного, не здатного принести хоч якісь результати.

Ще один епізод з фільму німецького класика спадає на думку. Перед враженими очима одного $з$ героїв гігантська машина перетворюється на ідола - криваве божество Молох, в палаючу пащу якого скидають усе нові й нові жертви.Так і друг головного героя, втративши роботу, втративши надію, зводить свої рахунки з життям, кинувшись у палаюче жерло печі.

I тут ми звернемо увагу на наявність у стрічки Васяновича тих основних стихій, які й стають ключем до розуміння й трактування і сюжетних мотивів, і доль героїв. Як зазначалося, вогненна стихія, згідно з аналітичною психологією К. Г. Юнга, пов'язана з чоловічим началом. І от коли чоловік втрачає 
себе, своє місце в житті, єдине що йому залишається-повернутися у свою стихію, віддати себе вогню.

Головний герой знаходить тут собі цілком прозаїчну роботу - розвозити воду у цистерні. Проте і ця проза життя набуває на екрані символічного забарвлення. Війна отруїла землю Донеччини, наситила iii своїми смертоносними відходами. I от тепер вода стає тією цілющою субстанцією, що має не лише напоїти тіло, а й оживити також душу людини. У цьому плані показовий епізод купання головного героя у ковші екскаватора, коли він немов змиває з себе бруд і біль війни, відроджуючись до нового життя.

Під час виконання героєм своєї місії-саме так сприймається ота його прозаїчна робота, відбуваються дві доленосні зустрічі. Вони відбулися саме тоді, коли він, умовно кажучи, відійшов від сфери вогню (від свого ливарного виробництва) і наблизився до стихії води - жіночого начала.

Обравши поствоєнну епоху, автор «Атлантиди» фокусує увагу на тих катастрофах, що спіткають людину, коли вже відійде в минуле зовнішня небезпека. I коли починають вириватися назовні «демони позасвідомого».

У фільмі відбуваються зустрічі $з$ двома жінками. I кожна $з$ них - то два такі відмінні шляхи порятунку. Один - то прекрасна перспектива знайти свій земний рай, поринути в світ матеріального благополуччя. Але Сергій не користується цим чудовим шансом. Так, можна змінити місце свого перебування, вписатися в благополучний цивілізований світ. А чи позбудеться там герой своїх «демонів позасвідомого», чи не втратить він себе як особистість? Він залишається. Залишається на цій випаленій, знівеченій землі, яка невідомо ще коли відродиться, та чи й відродиться взагалі.

Інша жінка, навпаки, належить цій повоєнній пустелі. Вона в цьому світі вже знайшла себе, повертає йому пам'ять. Це волонтерка місії «Чорний тюльпан». 3 надр землі повертаються тлінні рештки тих, хто колись поліг на ній. 3 відстороненістю і науковою об' єктивністю йде опис того, що лежить тепер у чорних пластикових мішках.

С таке гірке, але точне прислів'я: «Війна не закінчилась, поки останній солдат не похований». Та виникає надія, що війна кінець кінцем закінчиться і в душах людей. Сергія рятує кохання. Ерос (любов) і Танатос (смерть) ідуть поруч. Та саме кохання допомагає чоловікові вистояти у найскладнішому протистоянні, у боротьбі з самим собою.

До речі, еротична сцена сприймається цнотливо, без подробиць, вона радше нагадує стародавню фреску, що оживає. Ці кадри прозвучали певною мірою полемічно до кадрів фільму, що їх Васяно- вич знімав як оператор. Мається на увазі «Плем'я» М. Слабошпицького, де в еротичних сценах панує лише тваринний потяг. Уважні критики помітили і відмінності авторських меседжів у фільмі «Атлантида» і стрічці того ж таки Слабошпицького «Ядерні відходи». Там теж випалена радіацією пустеля, але люди на ній мають такі самі випалені душі. Точніше, ми там бачимо лише самі тіла, що відправляють свої потреби, але душа, духовність то для них terra incognita.

Земля на екрані сприймається знов-таки як мати - і жорстока, яка поглинає, і така, що захистить і врятує, поверне світові пам'ять, що стане запорукою безсмертя.

Споглядаючи майже «інопланетні» ландшафти випаленої війною Донецької землі, режисероператор відтворює небо над цим простором, яке здається справді свинцевим. Тут не відчувається вільного руху повітря, яке «віє, де хоче». Під цим небом ми бачимо кар' єри, в яких вже нічого не добувається, розбиті дороги, чорні ями, звідки дістаються рештки загиблих.

I хоч як дивно, певну рівновагу і спокій принесе ніч. Тоді не видно тих страшних виразок, що їх завдала землі війна. Темний серпанок ночі містить у собі надію на неминучий світанок. I як провісник його, як вранішня зоря з'являються обличчя закоханих, осяяні червоним світлом. Знову повертається візуальна тема вогню - але це вогонь життя, вогонь кохання. Він, наче досвітня зірка, осяює темряву ночі. І ми роздивимось, нарешті, обличчя цих людей, освітлених життєдайним почуттям. Режисер іде на пряму умовність, подаючи їх неначе в освітленому медальйоні, який викарбувався на темному тлі неба.

Український арт-кінематограф суворий, він не часто пробуджує в серцях надію. Та стрічка Валентина Васяновича все ж таки обіцяє світанок після нічної темряви. У цьому фільм суголосний 3 творіннями класиків української «поетичної школи» і знаних митців світового кіно, які, вражаючи серця глядача найтрагічнішими картинами буття, привносили до них світло, звертаючись до довічних символів природи, що розкривають шлях до відродження людського духу.

Висновки. Тотальна урбанізація, здавалось би, назавжди віддаляє сучасну людину від природи. Ми звикаємо жити в «кам'яних джунглях», і цей рукотворний світ по-своєму приваблює, бо він $€$ результатом творчості багатьох поколінь людства. Не дивно, що місто стає тим середовищем, де митці теж черпають своє натхнення.

Втім, відбувається рух і у зворотному напрямку. Природа, що тривалий час була полем практич- 
ної діяльності, «не храмом, а майстернею», постає зовсім в іншому світлі. Ні, було б наївно думати, що людина знову, як в прадавні часи, почне обожнювати природні стихії. Наш сучасник шукає на теренах природи розради від шаленого ритму життя. А в мистецтві природні стихії стають віддзеркаленням станів людської душі. I їі міфологічні та фантастичні образи, що втілювали в собі уявлення про природні стихіі, несуть в собі поетичне бачення як людської особистості, так і навколишнього світу.

\section{Джерела та література}

Баткин, Л. (1991). Не боясь своего голоса. Мы и фильмы Андрея Тарковского. Москва: Искусство. 398 с.

Башляр, Г. (1998). Вода и грезы: опыт о воображении материи. Москва: Изд-во гуманитарной литературы. 268 с.

Делез, Ж. (2004). Кино: кино 1. Образ-движение; Кино 2. Образ-время. Москва: Ад Маргинем. 622 с.

Оніщенко, О. (2001). Художня творчість в контексті гуманітарного знання. Київ: Вища школа. 179 с.

Ремез, Г. (1929). Патос землі. Кіно. № 16, серпень. 19 с.

Тримбач, С. (2007). Олександр Довженко: загибель богів. Ідентифікаиія автора в національному часо-просторі. Вінниця: Глобус-Прес. 800 с.

Феллини, Ф. (1984). Делать фильм. Москва: Искусство. $287 \mathrm{c}$.

Феллини, Ф. (1988). Феллини о Феллини. Москва: Радуга. $478 \mathrm{c}$.

Эйзенштейн, С. (1964). Неравнодушная природа // C. Эйзенштейн. Избранные произведения в 6-ти томах. Москва: Искусство. Т.3. 670 с.

Юнг, К.-Г. (1991). Архетип и символ. Моква: Ренессанс. 304 с.

Юнг, К.Г. (2001). Психология безсознательного. Москва: Издво АСТ. Канон. 399 с.
Якимович, А. (1994). Довженко и новая «первобытность». Киноведческие записки. Вып. 23. М. 253 с.

\section{References}

Batkyn, L. (1991). Ne boyas' svoeho holosa. [Being not afraid of the voice]. My y fil'my Andreya Tarkovskoho. Moskva: Iskusstvo. $398 \mathrm{~s}$. [in Russian]

Bachelard, G. (1998). Voda y hrezy: opyt o voobrazhenyy materii [Water and dreams : experience about imagination of matter]. Moskva: Izd-vo humanytarnoy lyteratury. 268 s. [in Russian]

Deleuze, G. (2004). Kino: kino 1. Obraz-dvyzhenye; Kino 2. Obraz-vremya. [Cinema: the cinema 1. Character-motion; Cinema 2. Character-time]. Moskva: Ad Marhynem. 622 s. [in Russian]

Onishchenko, O. (2001). Khudozhnya tvorchist'v konteksti humanitarnoho znannya [Artistic work is in the context of humanitarian knowledge]. Kyiv: Vyshcha shkola. 179 s. [in Ukrainian]

Remez, H. Patos zemli [Pathos of the earth]. Kino. 1929. № 16 serpen'. 19 s. [in Ukrainian]

Trymbach, S. (2007). Oleksandr Dovzhenko: zahybel' bohiv. Identyfikatsiya avtora $v$ natsional'nomu chaso-prostori [Oleksandr Довженко : death of Gods]. Vinnytsya: Hlobus-Pres. 800 s. [in Ukrainian]

Fellini, F. (1984). Delat' fil'm [To do a film]. Moskva: Iskusstvo. 287 s. [in Russian]

Fellini, F. (1988). Fellini o Fellini [Fellini about Fellini]. Moskva: Raduha. 478 s. [in Russian]

Eisenstein, S. (1964). Neravnodushnaya pryroda [Not indifferent nature] / S. Eisenstein. Yzbrannye proyzvedenyya v 6-ty tomakh. Moskva: Iskusstvo. T. 3.670 s. [in Russian]

Jung, K.-G. (1991). Arkhetyp i symvol [Archetype and symbol]. Moskva: Renessans. 304 s. [in Russian]

Jung K.-G. (2001). Psykholohyya bezsoznatel'noho [Psychology of unconscious]. Moskva: Izd-vo AST. Kanon. 399 s. [in Russian]

Yakimovych A. (1994). Dovzhenko y novaya «pervobytnost'» [Dovzhenko and new primitive «state»]. Kynovedcheskye zapysky. Vyp. 23. Moskva, 1994. 253 s. [in Russian]

\section{Oksana Moussienko}

\section{Symbolism of the elements as a meaning-making factor in cinema}

Abstract. This article is a study of the influence of the symbolism of natural elements on the figurative system of audiovisual arts, in particular on cinematography. The author analyzes films in which these influences were manifested most expressively, namely the works of O. Dovzhenko, J. Vigo, F. Fellini, A. Tarkovskiy, Yu. Ilyenko.

Key words: symbol, archetype, mythologeme, poetics, element. 